panied -by dark lines on their more refrangible sides. With the 10-inch refractor and Maclean spectroscope, $\mathrm{C}$ was seen to be very brilliant, and there were four very conspicuous lines in the green. Several fainter lines were also seen, and a dark line was suspected in the orange. Mr. Lockyer noticed that some of the lines, especially the bright ones near $F$ on the less refrangible side, appeared to change rapidly in relative brightness, and this was confirmed by Mr. Fowler. All the lines in the spectrum of the Nora are broad, although in a photograph of the spectrum of Arcturus, taken with the same instrumental conditions, the lines were perfectly sharp. It is also important to note that the broadening of the lines is not accompanied by any falling off of intensity at the edges, as in the case of the hydrogen lines in such a star as Sirius.

Judging from the testimony here given, it is undoubtedly true that a new star has appeared to our vision, and given astronomers an opportunity to study its make-up. It cannot, however, be said that the object has suddenly come out to its present magnitude. The probability points to the fact that the new star is a variable of long period, and one that at its minimum sinks to invisibility. The verification of this statement must rest upon future observations. We have no record that indicates that a star as bright as the tenth magnitude has ever occupied the place in which the new star has been found. All speculation as to its future history is valueless, because we know nothing of its past history.

The star is now being constantly watched by all the powerful telescopes and spectroscopes of the world, its image is almost nightly caught upon the photographic plate handled by men of experience, and it will not sink back into invisibility without leaving behind a record of great value.

Washington, D.C., March 9.

GEO. A. HILL.

\section{THE TIMBER TREES OF WEST VIRGINIA.}

The Guyandot Coal Land Association, which is the owner of over 200,000 acres of land in the basins of the Guyandot and Twelve-Pole Rivers, in the Counties of Wayne, Logan, and Lincoln, near the south-west corner of West Virginia, has recently had the large timber trees on about 9,000 acres of land counted and measured, thus securing reliable information as to the actual present condition of the Trans-appalachian forests of that region. The diameter of the trees was taken, with calipers, at about four feet above the ground; then the length of the trunks suitable for cutting into $\operatorname{logs}$ or for long timber was carefully estimated by the eye of the skilful timber measurer. No trees were measured that were less than eighteen inches in diameter, except the hickories and locusts, which were measured from ten inches and upward. The detailed tables of this counting and measuring have been furnished me for inspection. I think that a summary of the detailed count of the results of the measurements on one single tract will be of interest to the readers of Science. For this purpose I select a tract of 655 acres on the top of the dividing ridge between the waters of the east and the west forks of Twelve-Pole River, two miles northeast of the new mining town of Dunlow on the Ohio extension of the Norfolk and Western Railroad, about forty miles by rail south-east from the Ohio River at the new town of Kenova, one named from the abbreviation names of the three States that are there adjacent.

About one-half of this particular tract of land, say 325 acres, lies on the east side of the dividing ridge, slopes from the divide.and faces to the north of east, and drains into
East Twelve-Pole River. The other 325 acres lies on the west side of the divide, slopes to the south of west and drains into West Twelve-Pole River. The crest of the divide is not far from 1,000 feet above the level of the sea. The following statement shows the whole number of large timber trees now growing on this tract of 655 acres, by kinds and exposures. This tract was found to have growing on it, 16,989 trees; an average of about 26 large timber trees to the acre.

\begin{tabular}{|c|c|c|c|}
\hline Kinds of Trees. & Western Slope. & Eastern Slope. & $\begin{array}{c}\text { Trees of Each } \\
\text { Kind. }\end{array}$ \\
\hline White oaks.............. & 1,256 & 730 & 1,986 . \\
\hline Chestnut oaks............. & 3,803 & 2,083 & 5,886 \\
\hline Black oaks............. & 734 & 366 & 1,100 \\
\hline Red oaks................ & 494 & 242 & 736 \\
\hline Hickories................. & 1,556 & 991 & 2,547 \\
\hline Chestnuts.................. & 1,203 & 697 & 1,900 \\
\hline 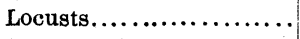 & 148 & 59 & 207 \\
\hline Maples............. & 224 & $1^{\prime} 6$ & 330 \\
\hline Birches.................... & 159 & 174 & 333 \\
\hline Tultp-poplars............ & 386 & 472 & 858 \\
\hline Pines.................... & 563 & 376 & 939 \\
\hline Lindens................. & 93 & 74 & 167 \\
\hline Totals............... & 10,619 & 6,370 & 16,989 \\
\hline
\end{tabular}

The proportionate percentage of the hardwood trees of the above table, all those named except the tulip-poplars, pines, and lindens, is quite remarkable. The softwood trees are: 1,042 on the westward slope and 922 on the eastward slope, a total of 1,964 , or less than ten per cent of the whole number of trees on the western slope, over fourteen per cent of those on the eastern slope, and nearly twelve per cent of the whole number of trees, leaving over ninety per cent of the westward slope trees and near eighty-six per cent of the eastward slope ones as hardwoods. So these hardwood trees constitute eighty-nine per cent of all the large counted and measured trees now growing on this tract of land. The figures of the table indicate that the large hardwood trees are more abundant on the westward exposure of the dividing ridge.

The record of the diameter and length of each of the trees embraced in the above list, that now lies before me, shows that most of these trees are of large size, the oaks ranging in diameter from eighteen to sixty inches, and in trunk length from twenty to sixty feet. The hickories range from ten to twenty-seven inches in diameter, and from fifteen to sixiy feet in trunk length; the pines from eighteen to forty inches in diameter, and twenty to seventy feet in trunk length; and the tulip-poplars from twenty to sixty-six inches in diameter, and from thirty to eighty feet in trunk length.

Staunton, Va. JED. HoTChKISS.

\section{THE SPECIALIST. ${ }^{1}$}

"MANY scientific men of excellent reputation are to-day guilty of the crime of unnecessary and often premeditated and deliberately planned mystification; in fact, almost by common consent this fault is overlooked in men of distinguished ability, if, indeed, it does not add a lustre to the brilliancy of their attainments. It is usually regarded as a

1 A few thoughts suggested by the address of the retiring president of the American Assuclation for the Advancement of sclence, delivered at the Indianapolis meeting, Augus:, 1890 , from wbich the quotations bere given are dianapolis
taken. 